\title{
Grocery Sales in Russia and in the Region: What Problems Can Sanctions Cause?
}

\author{
Vasiliy Kuimov \\ Yuliay Suslova \\ Eva Shcherbenko
}

Siberian Federal University

Email:kuimov1945@mail.ru

Doi:10.5901/mjss.2015.v6n4s4p345

\section{Abstract}

The article studies grocery sales development in Russia and in a particular region during the years of significant changes in the circumstances of international sanctions; considers both quantitative (number of stores, retail chains, etc.) and qualitative indicators (retail turnover, retail chains' location, changes in the grocery market). Against the background of sanctions against Russia and the ban on import of certain food products, the changes of prices and range of groceries in region's trade are analyzed. This article draws conclusions about changes in trade and the possibility of increase in the production and sale of foodstuff of domestic manufacture.

Keywords: trade, consumer prices, sanctions, chains

\section{Introduction}

In the Trade and Development Report for 2014, UNCTAD notes that "the world economy is not yet out of doldrums, in which it has been stuck for the past four years, and there is a growing danger that this state of affairs is becoming accepted as the "new standard." The merchandise trade grew slightly above $2 \%$ in volume in 2012-13, which is below the growth of global output" (Trade and Development Report, 2014)

Against this background, the analysis of trade in Russia and one of its regions-the Krasnoyarsk Region-can show the development trends against the background of the sanctions and internal development in Russia.

\section{Literature Review}

\subsection{Basic definitions}

The article contains the following definitions: Retail - the process of selling goods/services to consumers. Retail turnover - amount of goods and services sold to customers during a period. Price - the cost per unit of product or service. Retail chains - a group of retail outlets, which usually have some relations. Range of goods - set of goods in a particular retail outlet.

\subsection{General analysis of the problem. Trade development in Russia}

Trade plays a decisive role in providing maximum satisfaction of the needs of the population through the dynamic interaction of product supply and consumer demand. Factors of trade development show both the level of the purchasing capacity of the population, and the integrated impulse to the development of manufacture of the commodities in demand. Food products retail in Russia has consistently reported high growth rates. For example, from 2004 to 2014, the turnover of the sector increased by 4 times and amounted to more than 10 trillion rubles, the share of modern formats is more than 35\% (Trade development strategy in the Russian Federation for 2011 - 2015 and until 2020)1 ${ }^{1}$ In per capita terms, the countrywide turnover of the sector also demonstrates a strong growth, which leads to the development and growth of the respective trade companies and investments. Figure. 1.

\footnotetext{
${ }^{1}$ This work uses official statistics' data and results of own surveys of commercial enterprises and food market in the region
} 


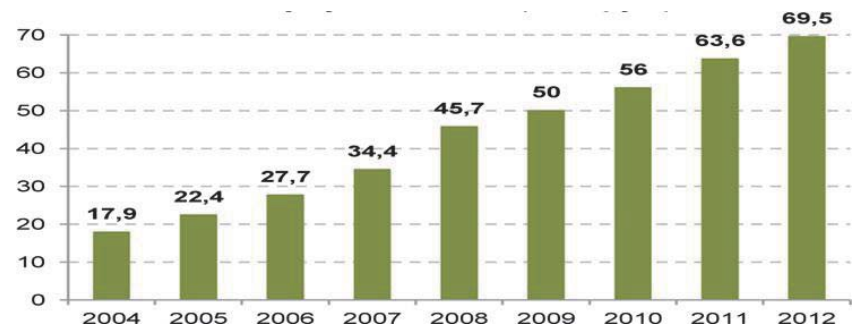

Figure 1. Retail turnover of food products in Russia in per capita terms (in thousand rubles) (Trade development strategy in the Russian Federation for 2011 - 2015 and until 2020)

Since 2008, the number of retailers selling groceries has been constantly growing and makes up nearly the third part of all enterprises.

High growth rates of the sector have allowed the Russian Federation to become one of the largest groceries retail markets in Europe. Certainly, the demand in Russia is being saturated, and its growth rate is slowing down, however, in comparison with developed countries, Russia still has significant potential for development (Figure 2).

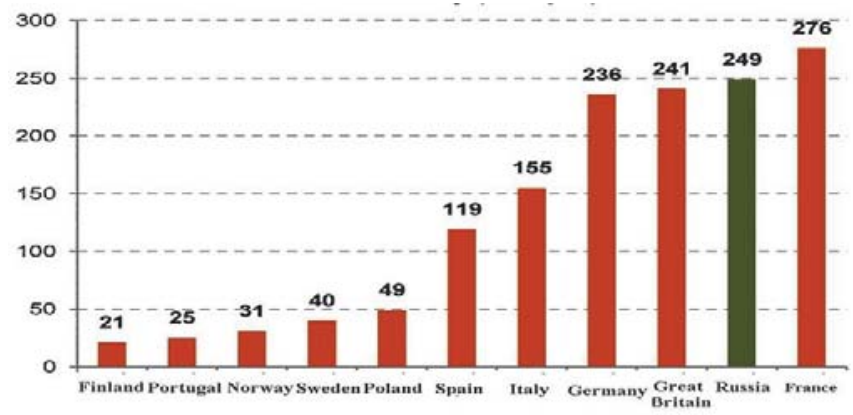

Figure 2. Retail turnover of groceries in Europe in 2012 (in billion US Dollars) (Trade development strategy in the Russian Federation for 2011 - 2015 and until 2020)

In accordance with the "Strategy of trade development in the Russian Federation..." (Trade development strategy in the Russian Federation for 2011 - 2015 and until 2020), Russian regions have adopted the minimum standards for the retail premises area, which is currently actively built. Some Russian cities-Moscow, St. Petersburg, Kazan, and other cities with a population more than a million - have highly developed retail chains comparable to the major capitals of European countries.

Transnational, federal, and regional retail chains have formed in the country and constantly increase their market share.

\subsection{Development of federal and regional retail chains in the region}

As of 2014, the Krasnoyarsk Region's grocery retail market equaled to 193.4 billion rubles, which is by $108 \%$ more than in the previous year. The food retail turnover totaled 69.07 thousands rubles per resident (Retail chains; Retail property market in Krasnoyarsk: situation and forecast, 2015).

An analysis of the activity of the major retail chains in the region shows that they continue to develop actively, increasing the competition among them (Table 1). 
Table 1. Main performance indicators of retail chains in Krasnoyarsk and the region in 2013-2014. (Retail chains; Retail property market in Krasnoyarsk: situation and forecast, 2015)

\begin{tabular}{|l|c|c|c|}
\hline Indicators & "Krasny Yar" & "Komandor" & "Spar" \\
\hline \hline Retail turnover, 2013, in million rubles & 6,118 & 6,345 & 3,150 \\
\hline Number of items sold under the retailer's own brand, pcs. & 971 & 1,175 & - \\
\hline Number of outlets, 01.07.2014, pcs. & 65 & 95 & 20 \\
\hline The total area of outlets, as of 01.07.2014, in sq. m. & 35,658 & 125,860 & 10,600 \\
\hline Number of products in stock, as of 01.07.2014, SKU & 28,400 & 31,000 & - \\
\hline Private label goods in stock, as of 01.07.2014, a\% & 2.4 & 5.0 & - \\
\hline Number of own brands, as of 01.07.2014, SKU & 240 & 352 & - \\
\hline
\end{tabular}

Grocery retailers increase their presence in the Krasnoyarsk Region and the cities of the region. Thus, in 2014, "Komandor" launched 18 new shops and "Krasny Yar" launched 6 new grocery stores. This is caused by both the logic of business development and the desire to strengthen their positions before the arrival of large federal and foreign retailers to the region. The consumer capacity has also been preserved. For the last year and a half, the average bill has grown at the level of the inflation-by $8-10 \%$. Therefore, retail chains develop comprehensively. Each of the grocery chains develops production of their own brands. The retail sector in the region has more than 21.500 facilities, with 510.49 sq. $\mathrm{m}$. per 1,000 people of retail area, serves more than 2.8 million consumers, and employs $16.6 \%$ of the employed population. The consolidation is growing - the retail chains' turnover makes $15.8 \%$ of the total turnover in the region (Retail chains; Retail property market in Krasnoyarsk: situation and forecast, 2015), and their share in the turnover increases (Table 2).

Table 2. Distribution and dynamics of the food market shares in Krasnoyarsk and the Krasnoyarsk Region, 2013-2014. Calculated by the authors based on their own researches (Retail chains; Retail property market in Krasnoyarsk: situation and forecast, 2015)

\begin{tabular}{|c|c|c|c|c|c|c|}
\hline \multirow{2}{*}{ Company name } & \multicolumn{2}{|c|}{ Retail turnover, million rubles } & \multicolumn{2}{|c|}{ Market share } & \multirow{2}{*}{$\begin{array}{l}\text { Market share } \\
\text { deviation }(+/-)\end{array}$} & \multirow{2}{*}{$\begin{array}{l}\text { Market share } \\
\text { growth rate, } \%\end{array}$} \\
\hline & 2013 & 2014 & 2013 & 2014 & & \\
\hline Retail chain "Komandor" & 6,345 & 7,527 & 0.035 & 0.039 & 0.004 & 111.429 \\
\hline Retail chain "Krasny Yar" & 6,118 & 7,398 & 0.034 & 0.038 & 0.004 & 111.765 \\
\hline Retail chain "Spar" & 3,150 & 4,600 & 0.018 & 0.024 & 0.006 & 133.333 \\
\hline Retail chain "Okay" & 4,800 & 5,200 & 0.026 & 0.027 & 0.001 & 103.846 \\
\hline Metro Cash\&Carry & 4,540 & 4,770 & 0.024 & 0.025 & 0.001 & 104.167 \\
\hline "Sibtreid" ("Desiatka", "Bigsi") & 1,980 & 2,400 & 0.011 & 0.012 & 0.001 & 109.091 \\
\hline $\begin{array}{l}\text { "Svezhie produkty" (brands } \\
\text { "Indiushkino","Sibirskaia guberniia") }\end{array}$ & 930 & 1,074 & 0.005 & 0.006 & 0.001 & 120.000 \\
\hline "Svetofor" & 750 & 830 & 0.003 & 0.004 & 0.001 & 133.333 \\
\hline Other retailers (markets, non-chain stores) & 150,587 & 159,600 & 0.84 & 0.825 & -0.015 & 98.214 \\
\hline Total & 179,200 & 193,400 & 1 & 1 & & \\
\hline
\end{tabular}

According to the data presented in Table 2, in Krasnoyarsk and the Krasnoyarsk Region in 2013-2014, the greatest share in food market had the group of "Other retailers." The market shares of this group of companies equal to $84 \%$ and $83 \%$ in 2013 and 2014, respectively. However, these values are the group total value of shares achieved in the course of activity of more than 4,000 retailers operating on the food market of the Krasnoyarsk Region. Thus, as shown by the market analysis performed in 2014, the market share of each company entering the group of companies is on the average equal to $0.02 \%$ of the value of the group total value of the market share.

As for the changing dynamics of market shares of analyzed companies, it should be noted that the positive trend of market share development in 2014, compared to 2013, was typical of almost each of the analyzed companies. The market share of the "Other retailers" group in 2014 decreased by almost 1.5\%, which strengthens the competition (Table 3). 
Table 3. Calculation of the indicators of competition intensity in the grocery retail market in Krasnoyarsk, 2013-2014. Calculated by the authors based on their own researches.

\begin{tabular}{|l|c|c|c|c|}
\hline Indicator & 2013 & 2014 & Deviation $(+;-)$ & Rate of change, $\%$ \\
\hline \hline Tripartite concentration ratio & 9.63 & 10.41 & 0.78 & 108.0996885 \\
\hline Herfindahl index & 0.709712 & 0.685716 & -0.023996 & 96.61891021 \\
\hline Rosenbluth index & 0.0114932 & 0.0667824 & 0.05528923 & 581.0605049 \\
\hline Entropy indicator & 0.0810003 & 0.0882899 & 0.00728962 & 108.9994913 \\
\hline Fractional concentration index & 1.6827 & 1.4923 & -0.1904 & 88.68485173 \\
\hline Market share dispersion & 65.880028 & 61.35191 & -4.5281174 & 93.1267221 \\
\hline
\end{tabular}

Thus, it can be concluded that in 2014 in Krasnoyarsk and the Krasnoyarsk Region, the grocery food market (with account of the intensity indicators) despite the consolidation was still lowly concentrated. Therefore, the competition intensity on this market remains rather high. Before the imposition of sanctions in the $1^{\text {st }}$ half of 2014, there had been an increase in the turnover share of the food retail, including beverages and tobacco products, which for the six months totaled 102.6 billion rubles.

Table 5. Retail turnover structure in the Krasnoyarsk Region in January-June 2014 (Retail chains)

\begin{tabular}{|l|c|c|c|}
\hline Indicators & Total, billion rubles & $\%$ & $\% 2013$ \\
\hline Retail turnover, total, including: & 234.3 & 100 & 100 \\
\hline Retail turnover of groceries, including beverages and tobacco products & 102.6 & 43.8 & 41.8 \\
\hline Retail turnover of non-grocery goods & 131.7 & 56.2 & 58.2 \\
\hline
\end{tabular}

\subsection{Sanctions, responses and range of grocery goods in region}

Recent changes in the political and economic situation in the world community have determined some changes in the functioning of Russia's and regional food markets.

The adopted Decree of the Government of the Russian Federation dated August 7, 2014 \#778 "On measures for implementation of Presidential Decree dated 07.08.2014 \#560 "On the application of certain special economic measures to ensure the security of the Russian Federation" (Decree of the Government of the Russian Federation dated 07.08.2014 \#778) restricted the import to Russia of certain agricultural products, raw materials, and foodstuffs. The ban concerned the goods produced in countries, which had imposed sanctions against Russian citizens and companies. In particular, all European Union countries, the USA, Canada, Australia, and Norway. The embargo included fruit, vegetables, nuts, fish, crustaceans, shellfish, poultry, cheese, milk and dairy products, frozen, fresh and cooled meat, both pork and beef, which had a sufficiently high market share. For example, the share of imported beef and cheese had reached 40 percent of the respective market. These measures have been introduced until 06.08.2015 and can be changed.

The modern regional food market is a complex mix of the efforts of regional food producers and food processors aimed at increasing the share of regional products, the efforts of neighboring regions and importers aimed at entering and consolidating in this market, and retailers who provide sale of these foodstuffs to the final consumer. In recent months, due to the current objective conditions, the operation parameters are changing for all of its participants. (Kuimov, Suslova, Shcherbenko, and Pankova, 2015; Borovinskii and Kuimov, 2014; Kuimov and Shcherbenko, 2015; Shcherbenko, 2011)

\subsection{Food production in the region}

The import restrictions for certain foreign products have given momentum to domestic agricultural producers for entering the market. Indeed, the raw material production industries (pork, beef, poultry, milk) have positive prospects. Pig and poultry farmers have now a good price-much higher than the prime cost, and meat is in demand, although last year, they had a bad financial situation, the selling price was below the prime cost, and many of them worked at a loss. (Kuimov, Suslova, Shcherbenko, and Pankova, 2015; Kuimov and Shcherbenko, 2015)

According to the data of 2014, the self-sufficiency of the Krasnoyarsk Region with baked goods, grain, eggs was more than $100 \%$, milk and dairy products-91.9\%, vegetables- $71.8 \%$, meat and meat products- $60.6 \%$, which are imported from neighboring regions: the Tomsk and Novosibirsk Regions, etc. To accelerate the production, it is 
necessary to have additional investments. The business stands ready to develop their projects. For example, "Rusagro," "Cherkizovo," "Sibirskaya Agrarnaia Gruppa," "Agropromkomplektatsiia," "Agroeko," "Kamskii bekon" declared a serious increase in their production. "Miratorg" (according to CEO of the National Union Pig Farmers) can also double their capacity.

Before 2014, a significant share in processing belonged to imported raw materials, particularly meat. Organization of new supplies, including local raw materials, required certain investment. Against this background, the tendency to achieve market results at the expense of the quality has increased.

\subsection{Retails and food prices.}

A review of opinions in press releases and expert assessments of the situation with sanctions shows that retail chains do not see significant changes for consumers on this issue. Experts of retail chains say that consumers coming to a store do not feel any product shortage.

According to PR-managers of such delis network as Krasny Yar and "Komandor," there is active replacement of banned products from other countries with similar Russian foodstuffs. The most suffered category is elite cheeses. But even here, we have already found solutions (Table 6).

Table 6. Changes in the import of basic commodities listed in sanctions (based on the author's surveys of retailers)

\begin{tabular}{|l|l|l|}
\hline & Suppliers before sanctions & New suppliers \\
\hline Conservation & Ukraine and Europe & Belarus, China, and other Russian regions \\
\hline $\begin{array}{l}\text { Import cheese } \\
\text { (white, Danish Blue Cheese, Parmesan } \\
\text { cheese, etc.) }\end{array}$ & Europe & $\begin{array}{l}\text { Switzerland - is not a part of the European Union, } \\
\text { Argentina, Uruguay }\end{array}$ \\
\hline $\begin{array}{l}\text { Fish } \\
\text { Salmon, trout, capelin, etc.) }\end{array}$ & Norway, Denmark & $\begin{array}{l}\text { Russia's Far East, } \\
\text { Argentina, Faroe Islands }\end{array}$ \\
\hline Fruit, vegetables & Europe (mainly Poland) & $\begin{array}{l}\text { Central and Southeast Asia, Serbia, Turkey, Egypt, } \\
\text { China }\end{array}$ \\
\hline
\end{tabular}

For objective assessment of the processes, the authors conducted a "blitz monitoring," which showed that the retailers offer consumers a large variety of domestic products, both in regional and federal formats. The widest range of groceries is offered by such retail networks as "Lenta" and "Okay." Such chains as "Svetofor" and "Spar" achieve their competitive advantage due to the price factor and cutting the logistics costs and the costs for maintaining a large variety of goods (Table 7).

Table 7. The range of basic foodstuffs in the federal retail chains in Krasnoyarsk (items number/including imported items) (as of November 14, 2014) (based on the author's surveys of retailers)

\begin{tabular}{|l|c|c|c|c|c|}
\hline Foodstuff & Lenta & Svetofor & Okay & Spar & Metro \\
\hline 1. Milk & $25 / 1$ & 4 & $12 / 2$ & 6 & 15 \\
\hline 2. Sour cream & 12 & 3 & 8 & 5 & 8 \\
\hline 3. Curd & 9 & 2 & 4 & 2 & 1 \\
\hline 4. Eggs & 5 & 1 & 4 & 1 & 6 \\
\hline 5. Beef & 2 & 1 & 3 & 2 & 3 \\
\hline 6. Pork & 3 & 1 & 3 & 2 & 5 \\
\hline 7. Chicken & 3 & 1 & 4 & 2 & 6 \\
\hline 11. White bread (not sliced) & 5 & 1 & 3 & 3 & 3 \\
\hline 12. Rye bread (not sliced) & 3 & 1 & 3 & 1 & 3 \\
\hline 13. Buckwheat & 8 & - & $3 / 1$ & 2 & 11 \\
\hline 14. Rice & 16 & 1 & $4 / 1$ & 4 & 8 \\
\hline 15. Millet & 3 & 1 & 2 & 2 & 7 \\
\hline 16. Pasta - "horns" & $15 / 2$ & 1 & $11 / 1$ & 3 & $11 / 4$ \\
\hline 17. Spaghetti & $8 / 4$ & 1 & $10 / 6$ & 3 & $10 / 3$ \\
\hline 18. Butter & 37 & 5 & $16 / 2$ & 6 & 15 \\
\hline 19. Cheese & $57 / 15$ & $2 / 1$ & $31 / 7$ & $20 / 2$ & $14 / 2$ \\
\hline 20. Sunflower oil & 15 & 1 & 10 & 7 & $15 / 1$ \\
\hline 21. Fresh frozen fish, & $30 / 7$ & 4 & 12 & 10 & 10 \\
\hline 22. Sugar & 4 & 1 & $11 / 1$ & 1 & 13 \\
\hline
\end{tabular}


Studies have shown that regional retail chains form a wide choice of groceries for consumers: milk-from 7 to 28 items, sour cream-5-9 items, and on the average 15 kinds of sausage. The imported products are represented in only a few evaluated categories. These include pasta, cheese, and butter. Wherein import presents a certain proportion, the range is formed mainly by Russian goods. The share of local brands in the total turnover of leading regional chains increased and equals to approximately 20\%. The local goods-mayonnaise "Gastronom," beer "Ayan," dairy products "Istok," "Berezovka," and "Semenishna," "Iskra" are of greatest demand. All of these brands are the leaders in their product categories.

A few months after the imposition of trade restrictions, there are some groceries from countries, which were exposed of the import ban. This is explained by the available reserves and impairments by suppliers. Simultaneously, the number of goods of new suppliers-Argentina, Indonesia, and Kazakhstan—has increased.

\subsection{Price changes and commoditization of the regional market}

The income growth, pursuit of quality and service level explain the rise of average prices for certain types of foodstuffs. The data on the price level for foodstuffs provided for almost a decade shows their growth (Table 8).

Table 8. Consumer price indexes for food products in The Krasnoyarsk Region 2005-2013. (End of December of the previous year, \%) (Automatic)

\begin{tabular}{|l|c|c|c|c|c|}
\hline & 2005 & 2010 & 2011 & 2012 & 2013 \\
\hline Food products & 108.0 & 110.7 & 105.9 & 108.5 & 106.2 \\
\hline Meat and poultry & 112.2 & 106.6 & 105.1 & 111.2 & 94.6 \\
\hline Sausages and meat products and poultry & 111.5 & 106.8 & 108.7 & 108.0 & 104.1 \\
\hline Tinned meat & 115.5 & 106.2 & 105.0 & 106.9 & 102.4 \\
\hline Fish products & 111.6 & 105.9 & 108.7 & 104.1 & 107.9 \\
\hline Butter & 107.8 & 125.7 & 105.4 & 100.7 & 113.9 \\
\hline Sunflower oil & 100.5 & 119.6 & 109.1 & 103.4 & 97.5 \\
\hline Milk and dairy products & 110.8 & 120.0 & 107.9 & 105.0 & 111.0 \\
\hline Eggs & 80.7 & 114.9 & 108.6 & 98.5 & 138.4 \\
\hline Sugar & 99.2 & 124.0 & 79.8 & 101.4 & 105.7 \\
\hline Confectionery & 105.4 & 106.3 & 111.4 & 104.5 & 104.6 \\
\hline Bread and bakery products & 104.9 & 104.6 & 109.3 & 113.7 & 105.5 \\
\hline Grains and beans & 101.8 & 144.7 & 95.9 & 93.7 & 102.2 \\
\hline Pasta & 102.9 & 106.8 & 107.6 & 105.5 & 107.3 \\
\hline Alcoholic drinks & 105.3 & 107.6 & 108.8 & 111.7 & 112.6 \\
\hline
\end{tabular}

In 2014, because of the sanctions and limited food prices, the growth remained except sunflower oil, the average price for which decreased by $2.5 \%$.

During our research, taking into account the minimum and maximum prices for the product group, we have found that federal chains offer consumers significant price differentiation within product lines. Regional trade chains also offer consumers wide price differentiation by types of food products. It is difficult to single out a chain that would have the price levels lower than those of the others. The study does not take into account popular in modern practice of chains promotional products. The price difference is determined by the manufacturer, package type, and purchase batch.

Based on the research, we cannot unambiguously state a significant rise in prices during the period of sanctions and restrictions. The data of our studies are correlated with the official data statistics. The minimum price is higher than the average price only for chickens, which takes place in the regional chains. Specialists explain it with the hike in the prices of local producers, which in turn was caused by certain food shortage due to poultry farms' closure in the region and with a great demand for the Siberian chicken by processors from the central and western regions of Russia (Table 9). 
Table 9. Changes in some food products prices (based on the author's surveys of retailers)

\begin{tabular}{|l|c|c|c|}
\hline \multirow{2}{*}{ Item name } & $\begin{array}{c}\text { Average prices for food in the } \\
\text { Krasnoyarsk Region in April } \\
\text { 2014, in rubles }\end{array}$ & $\begin{array}{c}\text { The price level in November-December 2014, in } \\
\text { rubles (minimum-maximum prices of chains) }\end{array}$ \\
\cline { 3 - 4 } & 243.89 & Federal chains & Region chains \\
\hline Beef (besides boneless meat), kg & 108.70 & $219.0-710.0$ & $176.0-722.0$ \\
\hline Chickens (besides chicken legs), kg & 110.61 & $99.9-189.0$ & $124.0-280.0$ \\
\hline Frozen, not cleaned fish, kg & 352.24 & $60.0-1179.0$ & $97.4-1115.0$ \\
\hline Butter, kg & 76.45 & $70.0-700.0$ & $99.9-715.0$ \\
\hline Sunflower oil, I & 45.23 & $23.32-92.0$ & $35.00-90.00$ \\
\hline Drinking milk, I & 50.55 & $29.90-204.4$ & $26.0-239.0$ \\
\hline Eggs, 10 pcs & 41.58 & $33.30-59.90$ & $29.00-68.00$ \\
\hline Sugar, kg & \multicolumn{2}{|c|}{$30.90-254.8$} & $25.80-100.00$ \\
\hline
\end{tabular}

\section{Conclusion}

This performed study allow to conclude that after the introduction of international sanctions and Russia's responsive measure aimed to protect the food security, retail in foodstuffs continues to develop, including its new formats-chain stores. At the first stage of adaptation - from September to December 2014-some products prices rose along with the formation of substitution of the range of goods with foodstuffs of new importers' countries and own regional and interregional products. The price growth remained within and for some products below the inflation rate.

Conflict of interest. Authors acknowledge that provided data do not contain any conflict of interest.

Honorary mention. In the article, we used materials of the research conducted by the authors and the data of the federal and regional statistical office. Conclusions and recommendations on these materials were presented at the city forum to the government of the region and used in development. The authors enclose their gratitude to the chain stores' heads for the assistance in the research.

\section{References}

Borovinskii, D.V., \& Kuimov, V.V. (2014). Organizatsiia zakupochnoi deiatel'nosti v kommercheskom predpriiatii. Sinergeticheskii effekt integratsii (sovremennye metodiki raschetov) [Organization of procurement in commercial enterprise. The synergistic effect of integration (modern methods of calculation)]. Krasnoyarsk: Siberian Federal University [in Russian]

Decree of the Government of the Russian Federation dated 07.08.2014 \#778 "On measures for implementation of Presidential Decree dated 06.08.2014 \#560 "On the application of certain special economic measures to ensure the security of the Russian Federation" Retrieved from http://government.ru/media/files/41d4f8e16a0f70d2537c.pdf [in Russian]

Doklad o torgovle i razvitii [Trade and Development Report] (2014). UNITED NATIONS New York and Geneva. Retrieved from http://unctad.org/en/PublicationsLibrary/tdr2014overview_ru.pdf [in Russian].

Kuimov, V.V., \& Shcherbenko, E.V. (2015). Prodovol'stvennyi rynok Sibiri: vozmozhno li eksportirovat' v strany AziatskoTikhookeanskogo regiona [Siberian Food Market: Is it possible to export it to Asia-Pacific region]. Gumanitarnye Nauki Humanities, 8 (Supplement/C), 166-179 [in Russian]

Kuimov, V.V., Suslova, lu.Iu., Shcherbenko, E.V, \& Pankova, L.V. (2015). Marketingovye tekhnologii v razvitii rynkov prodovo I'stvennykh tovarov regionov Sibiri [Marketing technologies in Siberian food markets development]. Krasnoyarsk: Siberian Federal University [in Russian]

Oborot roznichnoi torgovli [Retail turnover]. Retrieved from http://krsk.fas.gov.ru/ [in Russian]

Roznichnye torgovye seti [Retail chains]. Retrieved from http://krasnoyarsk.dk.ru [in Russian]

Rynok torgovoi nedvizhimosti Krasnoiarska: situatsiia i prognoz [Retail property market in Krasnoyarsk: situation and forecast]. (2015) (Prep. by company GVA Sawyer). Sovremennaia torgovlia - Modern Retail, 3 [in Russian]

Shcherbenko, E.V. (2011). Marketing v formirovanii sistemy prodovol'stvennogo obespecheniia regionov [Marketing in system forming of regions food supply]. Novosibirsk: Iz-vo SO RAN [in Russian].

Trade development strategy in the Russian Federation for 2011 - 2015 and until 2020. Order of the MIT of Russia of March 31, 2011. Retrieved from http://old.minpromtorg.gov.ru/ministry/strategic/sectoral/9 [in Russian] 